\title{
The comparative advantage of South Africa soybean production
}

\author{
Yonas T. Bahta ${ }^{\star}$ and Johan Willemse \\ University of the Free State, Department of agricultural economics, P.O. Box 339, Internal box 58, 9300 Bloemfontein, South Africa
}

Received 14 May 2015 - Accepted 3 December 2015

\begin{abstract}
The effect of trade policy on the South African soybean industry is analyzed by using 4 digits Standard International Trade Classification of soybean (1201) data of 1996-2011. The Revealed comparative advantage (RCA), Hirschman index, Major export category, Effective rate of protection (ERP) and Nominal rate of protection (NRP) were calculated. The RCA of the soybean industry in South Africa has shown a revealed comparative disadvantage from 1996-2011. Hirschman index indicates that the soybean industry shows lower concentration throughout 16 years. Lower concentration reduces the impact of international trade risk due to the possibility of price fluctuation of the soybean product. MEC measurement also indicates that South Africa does not rely its international trade from the soybean industry. ERP and NRP were also calculated, using an enterprise budget for soybean production. The result shows that the ERP is negative, which indicates that the weighted input tariffs on soybean inputs amount are more than the output tariffs; that is an indication producers of soybean would be better off, everything else being equal, by not being protected through tariffs. The NRP is higher than the ERP which implies that the tariff applied on the output is higher than the tariff applied on inputs. The structure of the tariff schedule may have an important bearing on efficiency. Thus, the study recommended that an extremely dispersed and ill-chosen tariff structure implies that protection remains uneven and gains from openness may still be confined.
\end{abstract}

Keywords: Soyabean production / revealed comparative advantage (RCA) / effective rate of protection (ERP) / nominal rate of protection (NRP) / hirschman index $(\mathrm{H})$

Résumé - Les avantages comparatifs de la production de soja en Afrique du Sud. L'analyse de l'impact de la politique commerciale sur l'industrie du soja sud-africain a été faite à partir de données à quatre chiffres de la Classification type du commerce international de soja (1201) sur la période 1996-2011. L'étude calcule l'indice de l'avantage comparatif révélé (RCA), l'indice de Hirschman qui mesure la concentration du marché, la diversification des exportations (MEC), le taux effectif de protection (ERP) et taux nominal de protection (NRP). Le calcul du RCA de la production sud-africaine de soja pour la période 1996-2011 indique un désavantage comparatif. L'indice d'Hirschman révèle une faible concentration relative de l'industrie du soja au cours des 16 années. Cette faiblesse de la concentration limite l'impact du commerce international induit par de possibles fluctuations des prix du soja. Le MEC souligne également que les échanges internationaux de l'Afrique du Sud ne dépendent pas de l'industrie du soja ; il existe une possibilité de diversification de l'économie. L'ERP et le NRP ont également été calculés à l'aide d'un budget d'entreprise productrice de soja. L'ERP calculé est négatif et indique que les droits de douane pondérés sur les quantités d'intrants importés sont supérieurs aux droits de douane s'appliquant aux quantités exportées; ce résultat est une première indication de la manière dont le secteur du soja est soumis aux politiques douanières. Le NRP est supérieur à l'ERP, signifiant que les droits de douane reposant sur les produits exportés sont plus importants que ceux des intrants. La structure de la liste tarifaire peut avoir une incidence importante sur l'efficacité. Une structure tarifaire très dispersée et mal choisie a pour conséquence une variabilité du degré de protection et un confinement des gains résultant d'une ouverture. Ainsi, l'étude recommande un nouvel examen de la structure tarifaire des intrants de l'industrie du soja.

Mots clés : Soyabean production / revealed comparative advantage (RCA) / effective rate of protection (ERP) / nominal rate of protection (NRP) / hirschman index $(\mathrm{H})$

\section{Introduction}

The Bureau for Food and Agricultural Policy (BFAP) projects that 605000 hectares of soybeans could be planted

^ Correspondence: Bahtay@ufs.ac.za in South Africa by 2020, based on increased yields and growing demand for animal protein. As a result, soybean production could triple to 1.62 million tons by 2020 (BFAP, 2013). The expansion of soybean production in South Africa will be driven by growth in the livestock and poultry sectors as a rise in 
Table 1. Consumption of soybean meal and sunflower meal in South Africa.

\begin{tabular}{cccc}
\hline & 2009 (actual) & 2010 (estimated) & 2011 (estimated) \\
\hline Sunflower meal & 414 & 342 & 340 \\
Soybean meal & 874 & 972 & 1000 \\
Total & 1288 & 1314 & 1340 \\
\hline
\end{tabular}

Source: BFAP projects, 2013.

disposable income of the population will increase demand for animal protein. BFAP's predictions are based on an increased average soybean yield of 2.7 tons/hectare (South Africa's average soybean yield in the past 5 years is 1.7 tons/hectare) which will increase profit margins and give farmers the necessary incentive to increase the planted area under soybeans (BFAP, 2013).

In 2011, South Africa consumed about 1.3 million tons of oilseed meal for animal feed purposes of which approximately $70 \%$ is soybean meal (Tab. 1). More than $90 \%$ of the soybean meal consumed in South Africa is imported mainly from Argentina, as locally produced soybean meal is only about 100000 tons (BFAP, 2013).

Farmers are starting to realize that soybeans are an excellent choice for crop rotation with maize due to the fact that they replace nitrogen in the soil. The production of soybeans has been made relatively easier with the genetically modified (GM) cultivars that are available in South Africa and a better technology usage in soybean production. The increase in soybean production in South Africa is driven by both the increase in area planted as well as an increase in yields.

There are a number of reasons why agricultural commodities are continuous prospects for public protection. The three major problems that the industry faces are stability problems, income problems and foreign trade problems. There is wide, though not unanimous, agreement that markets for most agricultural products are more unstable than necessary for efficient use of resources and efficient management of buyers' expenditures (Bahta, 2004). Khor (2005) and ACET (2014) explained that world's most urgent problems is the distorting nature of global agriculture trade including instability in the markets, income losses resulting from terms-of-trade declines and global agricultural trade (trade negotiations). Sizable price, output and income fluctuations occur in agriculture because of notorious inelasticities of demand and supply, uncertainties in foreign markets, and the vagaries of weather, insects and diseases peculiar to farming. Most legislation to protect farmers and most programmes dealing with the marketing of agricultural products usually involve the term "stabilization" in some respect (Houck, 1986). The question, however, is whether this goal is actually achieved through the set of policies that are in place and whether they are sufficiently integrated to create an environment that increases efficiency to enhance competitiveness. More specifically, within the scope of this study the question focuses on the role of trade policy.

South Africa has substantially changed its trade regime over the last three decades. Prior to 1970 the country adopted a policy of import-substitution industrialization. Since then trade policy has shifted towards achieving greater openness, first through the stimulation of exports during the 1970's and 1980 's, and then later through a more concerted attempt at trade liberalization during the 1990's. The reduction in tariffs during the 1990s was pronounced. Quantitative restrictions were replaced with their tariff equivalents, although in the case of agriculture this led to an increase in protection. However, Groenewald (2001) argues that the failure of the previous South African government to participate in the agricultural discussions of the Uruguay Round resulted in a lack of negotiating skills and depth in terms of backroom competency to support negotiators. Consequently, the recommendations embedded in the South African World Trade Organization (WTO) modalities pertaining to protection, were mainly based on a general guideline that the customs duty should result in domestic production and consumption volumes more or less similar to those produced under import control (Bahta, 2004; Kraamwinkel, 1998; USAID, 2006).

South Africa also fixes the rate of customs duties on agricultural products at a level necessary to increase the price of imported products to the imported price level of the Southern African Customs Union (SACU). Cassim et al. (2004) also argues that little progress has been made in creating greater uniformity in the range and number of tariffs that exist in South Africa. One of the objectives of South Africa's WTO commitment was to reduce the overall tariff bands to 6 categories. However, there are currently still close to 50 bands (Bahta, 2004).

There are many reasons why a simplified tariff structure would be superior. One of the most important is from an administrative point of view, i.e. it would be much easier for customs to regulate products that fall into one of only 6 tariff bands. A highly dispersed and cumbersome tariff structure may cause protection to be uneven, and gains from openness may be limited. Moreover, with considerable tariff peaks, trade reform may not succeed in encouraging exports, especially in those sectors that rely on internationally competitive inputs. Cassim et al. (2004) is of the opinion that without resorting to a wholesale liberalization, simple streamlining of tariffs will ensure that tariffs peaks do not hinder efficiency.

The significance of the soybean sectors globally including South Africa is very important. To answer the questions appertaining to the effect of trade policy on the soybean sector is vitally important. The world has witnessed a rapid spread of economic regionalism and integration, especially in the last two decades (Rai, 2010). One of the most visible outputs from this expansion is the proliferation of Free Trade Agreements (FTAs) among nations. The South African government engaged in a large number of FTAs. These conditions create a need to critically evaluate the role of trade policy in the soybean sector.

The objectives of this study is to analyze the trade policy of the soybean industry in South Africa and apply theoretical and empirical principles of Revealed comparative advantage 


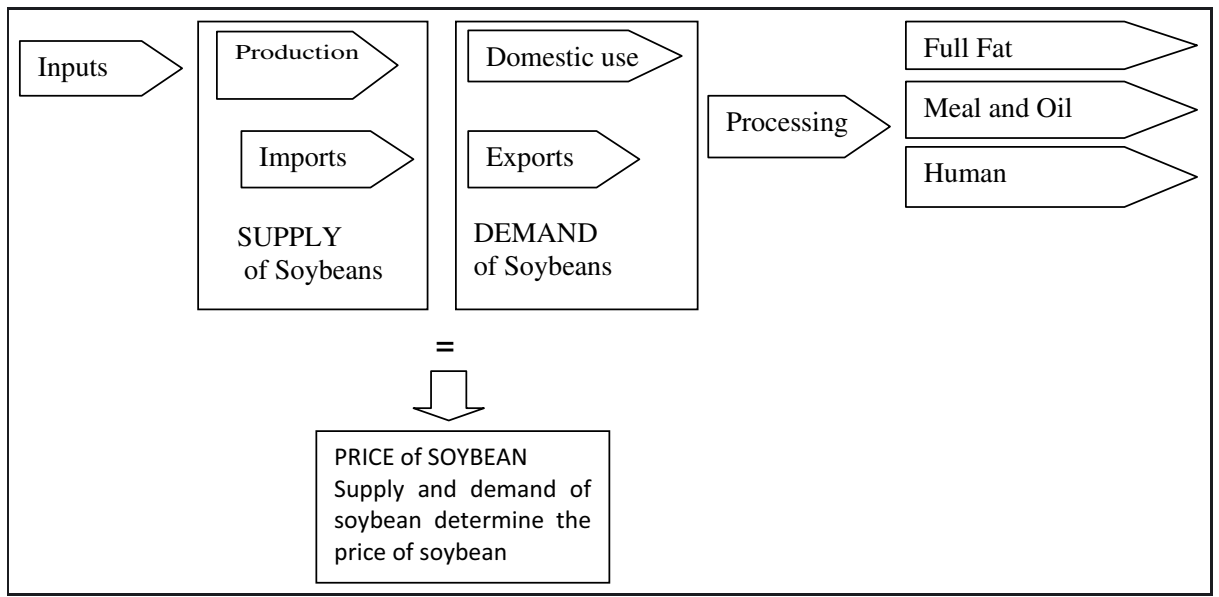

Fig. 1. Simple Soybean Value Chain and Balance Sheet. Source: Adapted from National Agricultural Marketing Council (NAMC), 2011.

(RCA), Hirschman index (H), Major export category (MEC), Effective rate of protection (ERP) and Nominal rate of protection (NRP) to better understand a national pattern of production and export of soybean in South Africa.

\section{Overview of the South African Soybean sector}

Domestic soybean meal production meets only $10 \%$ of the domestic soybean meal demand. The demand for soybean meal is driven by the animal feed industry, especially the poultry industry. Soybean meal imports were predicted to increase by $9 \%$ annually from 2005 to 2020 . During the same period, domestic production of soybean meal increased by $20 \%$ annually (NAMC, 2011).

The price of soybeans in South Africa is influenced by the international soybean price, the price of imported soybean meal and the cost of crushing soybeans. Since South Africa is a net importer of soybean meal and soybean oil, the domestic price of soybean meal and soybean oil will trade close to the import parity price of soybean meal and oil (Dlamini et al., 2014; NAMC, 2011).

A value chain framework will ensure that all aspects of the soybean industry are covered, whereas the supply and demand balance sheet will aid in the explanation of the price formation process of soybeans and soybean products (Fig. 1).

The compounded annual growth rate (CAGR) of South African Soybean meal export (2001-2009) was $-3.5 \%$, while the CAGR of South African soybean meal import (2001-2009) showed a CAGR 14\%. Indicating an increase in South African soybean meal imports while South African soybean meal exports decrease (Figs. 2 and 3).

\section{Methodology and data}

The broad definition of a trade indicator is an index or a ratio which can be used to describe and assess the state of trade flows and trade patterns of a particular country and can be used to monitor theses flows and patterns over time. Indicators can and should be used towards evidence-based policy-making

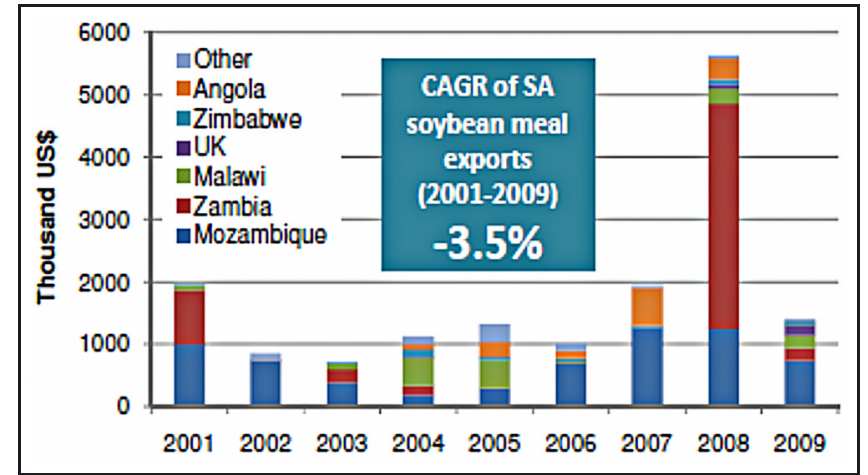

Fig. 2. Soybean meal exports by South Africa. Source: NAMC 2011.

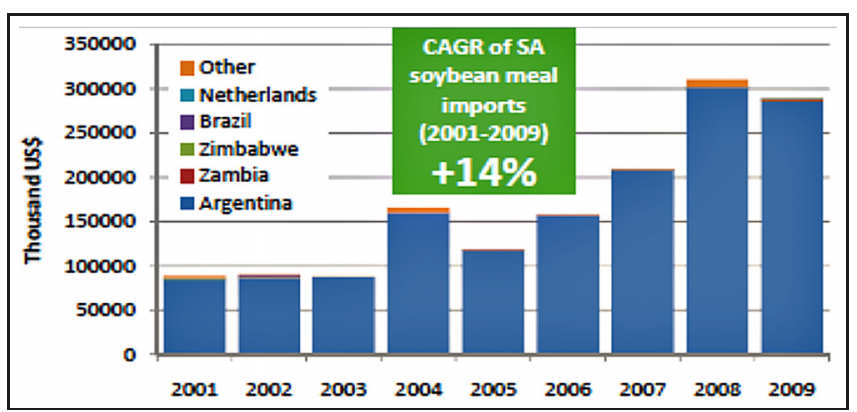

Fig. 3. Soybean meal imports by South Africa. Source: NAMC 2011.

(Scott, 2005). This study applies theoretical and empirical principles of RCA, Hirschman index (H), MEC, ERP and NRP to better understand the national pattern of production and export of soybean in South Africa using 4 digits SITC of soybean (1201) data of 1996-2011 and Enterprise budgets for the Free State Province (FSP) and KwaZulu-Natal Province (KZN) for the year 2009/2010.

\subsection{Data sources}

The trade data used, was obtained from United Nations commodity trade statics (UN COMTRADE) and the Department of Trade and Industry (DTI), of the Republic of South Africa. 
Enterprise budgets for the free state province (FSP) and KwaZulu-Natal Province (KZN) were obtained from Grain South Africa for the year 2009/2010. The economic price of soybean was calculated by giving due consideration to the shadow value of the exchange rate, transportation cost, cost insurance freight (CIF), import parity price (IPP) as well as tariffs imposed on inputs obtained from South Africa foreign exchange trading (SAFEX). However, the source of data did not include the costs for the non-tradable inputs such as electricity and labour. This analysis is therefore limited to the reporting of effective rates of protection, according to the Balassa method, the analysis is limited to the gross margins soybeans.

\subsection{Economic model}

RCA, Hirschman index $(\mathrm{H})$ and MEC calculated based on the data of production and export of soybean in South Africa using 4 digits SITC of soybean (1201) data of 1996-2011.ERP and NRP calculated based on the data of Enterprise budgets for the Free State Province (FSP) and KwaZulu-Natal Province (KZN) for the year 2009/2010, shadow value of the exchange rate, transportation cost, cost insurance freight (CIF), import parity price (IPP) as well as tariffs imposed on inputs.

\subsubsection{Revealed comparative advantage (RCA)}

In 1965, Bela Balassa introduced a notion of RCA as a way to approximate comparative advantage in self sufficiency. According to Belassa, the concept of RCA pertains to the relative trade performance of individual countries in particular commodities. On the assumption that the commodity pattern of trade reflects inter-country differences in relative costs as well as in non-price factors, this is assumed to reveal the comparative advantage of trading countries. Balassa (1977) mentioned that, if trade performance is determined by comparative advantage, then direct observations of trade performance should reveal comparative advantage. Barring production or export subsidies, the stronger a nation's relative trade performance in a certain commodity, the greater the comparative advantage in the production of the commodity. The plausibility of this condition has almost certainly been strengthened by the trends in trade liberalization (Leishman et al., 1999). In this paper the RCA is used to analyze the comparative advantage and export pattern of soybean and provides valuable information for trade policy in South Africa.

RCA index mimics a specific country's comparative advantage but is often incorrectly presented as an exact measure of comparative advantage. However, it provides a basis for assessment of a country's export potential. The index can be tracked overtime or compared across countries to gauge if a country trade is developing in the right direction. The formula to calculate Balassa RCA index is:

$$
\mathrm{RCA}_{i}=\frac{X_{i j}}{\sum_{i} X_{i j}} \mid \frac{\sum_{j} X_{i j}}{\sum_{i} \sum_{j} X_{i j}},
$$

where

$X_{i j} \quad$ is the exports of sector " $i$ " of country " $j$ "; $\sum_{i} X_{i j} \quad$ is the total exports of country " $j$ "; $\sum_{j} X_{i j} \quad$ is the world exports of sector " $i$ "; and $\sum_{i} \sum_{j} X_{i j}$ is the total "world" export.

This index measures a specific product's share in the country's total export relative to a share of this product in the world trade. When the product's share in national exports is higher than the product's share in the world export $(\mathrm{RCA}>1)$, interpret it as the country revealed comparative advantage in this particular product. In contrast, for products whose $(\mathrm{RCA}<1)$, country is said to reveal comparative disadvantage. Often this index is interpreted as RCA in production of product.

According to Mikic (2005), there is a vast literature available dealing with both theoretical and empirical principles of RCA. Furthermore, we should stress that no country is free from government policies and interventions, which distort trade flows and therefore cause a high probability that the RCA index misrepresents true comparative advantages. One should however note that government intervention and level of national, sectoral or firm level competitiveness inversely correlated. In other words, most intervention are not competitive (or have not been competitive) and assumed that intervention cannot fully mask the existing comparative disadvantage. Therefore, sectors found as revealing comparative disadvantage should then become even less competitive when intervention removed. The RCA indices therefore are still of significant use in tracing out national competitive advantages.

\subsubsection{Export diversification index}

Export diversification has been measured in many ways. For instance, it has been measured using concentration indexes, counts of exported products or even indexes that take into account the productivity content of the export basket (Hausmann and Klinger, 2006). This study use concentration indexes, counts of exported products with the aim of assessing and monitoring of export performance and competitiveness of the soybean sector of South Africa.

Export diversification is usually held to be important for developing countries. This is because, many developing countries are often highly dependent on relatively few primary commodities for their export earnings. Unstable prices for these commodities may subject a developing country exporter to serious terms of trade shocks. Since the co-variation in individual commodity prices is less than perfect, diversification into new primary export products is generally viewed as a positive development. The strongest positive effects are normally associated with diversification into manufactured goods, and its benefits include higher and more stable export earnings, job creation and learning effects, and the development of new skills and infrastructure that would facilitate the development of even newer export products. The export diversification (DX) index for a country is defined as:

$$
\mathrm{DX}_{j}=\frac{\sum_{i}\left|h_{i j}-h_{i}\right|}{2},
$$

where

$h_{i j}$ is the share of commodity " $i$ " in the total exports of country " $j$ ".

$h_{i}$ is the share of the commodity in world exports. 
The related measure used by United Nations Conference on Trade and Development (UNCTAD) is the concentration index or Hirschman $(\mathrm{H})$ index, which is calculated using the shares of products in a country's exports:

$$
H_{j}=\sqrt{\left(\sum\left(x_{i} / X\right)^{2}\right)}
$$

where $X_{i}$ is value of product i's export and $X$ is value of total exports of country.

The lower the index, the less concentrated are a country's exports. This index is normalizing so that its values range between 0 and 1 . Values closer to one indicate more concentrated trade structures. It is generally assumed that lower export concentration reduces the impact of international trade risks due to the possible price fluctuations of specific products (World Bank, 2013).

\subsection{Major export category (MEC)}

MEC identifies a product category " $i$ " that accounts for 50 percent or more of total export and in this way dominates country j's exports. For each exporting product " $i$ " a share in total countries " $j$ " exports are calculated and ranked. If there is a single product with a share of 50 percent or higher, a country is deemed to be too dependent on one product category for its exports.

$$
M X_{i}=\frac{x_{i j}}{\sum_{i=1}^{n} X_{i j}} \times 100,
$$

where $X_{i j}$ is value of product " $i$ " exports of country " $j$ " and $\sum_{i} X_{i j}$ is value of total exports of country " $j$ ".

If no single category accounts for $50 \%$ or more of total exports, the economy is classified as diversified. Identification of dominating products in a country's trade is valuable 'back of the envelope' result for both trade policy and adjustment management.

\subsubsection{Effective rate of protection (ERP) and nominal rate of protection (NRP)}

ERP is a commonly used measure of net effect of trade policies on the incentives facing domestic producers. The measurement of effective protection is clearly a two-stage process - firstly, determining the nominal protection of the policies in question, and secondly, analyzing the implications for effective protection to different firms, sectors or activities (Flatter, 2002).

Effective rates of protection can be derived from the following basic formula:

$$
\mathrm{ERP}=\frac{V A^{d}-V A^{w}}{V A^{w}} \times 100
$$

where: $V A^{d}$ is value added in the activity as measured at protection-inclusive domestic prices and $V A^{w}$ is value added in the activity as measured at undistorted world prices.

NRP on any product is the proportional difference between its domestic and international price arising from the trade policies in question. These policies can include import tariffs, export taxes, quantitative restrictions (licensing requirements, prohibitions, rules of origin, local purchase requirements, etc.) and other 'incentives' such as subsidies and tax rebates. If the only relevant trade policy were a $20 \%$ import tariff, the NRP would be $20 \%$ - the proportional difference between the cost insurance freight (CIF), import price and landed price (and therefore of closely competitive locally produced goods) in the domestic market. With a more complex set of trade policy measures the NRP is an estimate of the equivalent ad valorem tariff that would lead to the same difference between domestic and international prices as prevails under the policies in question.

NRP, therefore, is a measure of the total price-raising (or reducing) effects on a tradable good of the trade policies being examined. The relationship between the domestic price and the world price of any good, and the derivation of NRP from this, can be expressed algebraically as:

$$
\begin{aligned}
P^{d} & =P^{\mathrm{w}}(1+t+d+e) \\
\mathrm{NRP} & =\frac{p^{d}-p^{w}}{p^{w}} \times 100,
\end{aligned}
$$

where

$P^{d}$ is domestic price;

$P^{w}$ is world price;

$t$ is ad valorem equivalents of taxes;

$d$ is duties on imports of the good; and

$e$ is the net ad valorem tariff equivalent of other non-tax, non-tariff trade restrictions.

\section{Interpretation of results}

The importance of the soybean industry for the South African economy is undeniable. The government of South Africa recognises the importance of soybeans in the economy. The Industrial Policy and Action Plan (IPAP) 2012/132014/15 distinguishes soybeans as having the potential for creating opportunities for new investments and job creation. These policy directives have elevated soybeans as both a cash and food crop. In the process multinational seed companies have been enticed to develop improved soybean seed varieties that can perform in a wide spectrum of localities or that are locality specific, year after year (De Beer, 2012 cited by Dlamini et al., 2014).

\subsection{Revealed comparative advantage (RCA)}

RCA of the soybean industry in South Africa has shown a revealed comparative disadvantage during the study period of 1996 to 2011. South Africa is a net importer of soybean, i.e. imports exceed exports because local production does not meet the local demand for soybean. This situation has not changed from 1996 to 2011 (Tab. 2).

RCA measures do not explain why a country is competitive in different products, but elucidate in more accurate ways relative to a simple analysis of export trends - how a country features in the context of world trade (Cassim et al., 2004). 


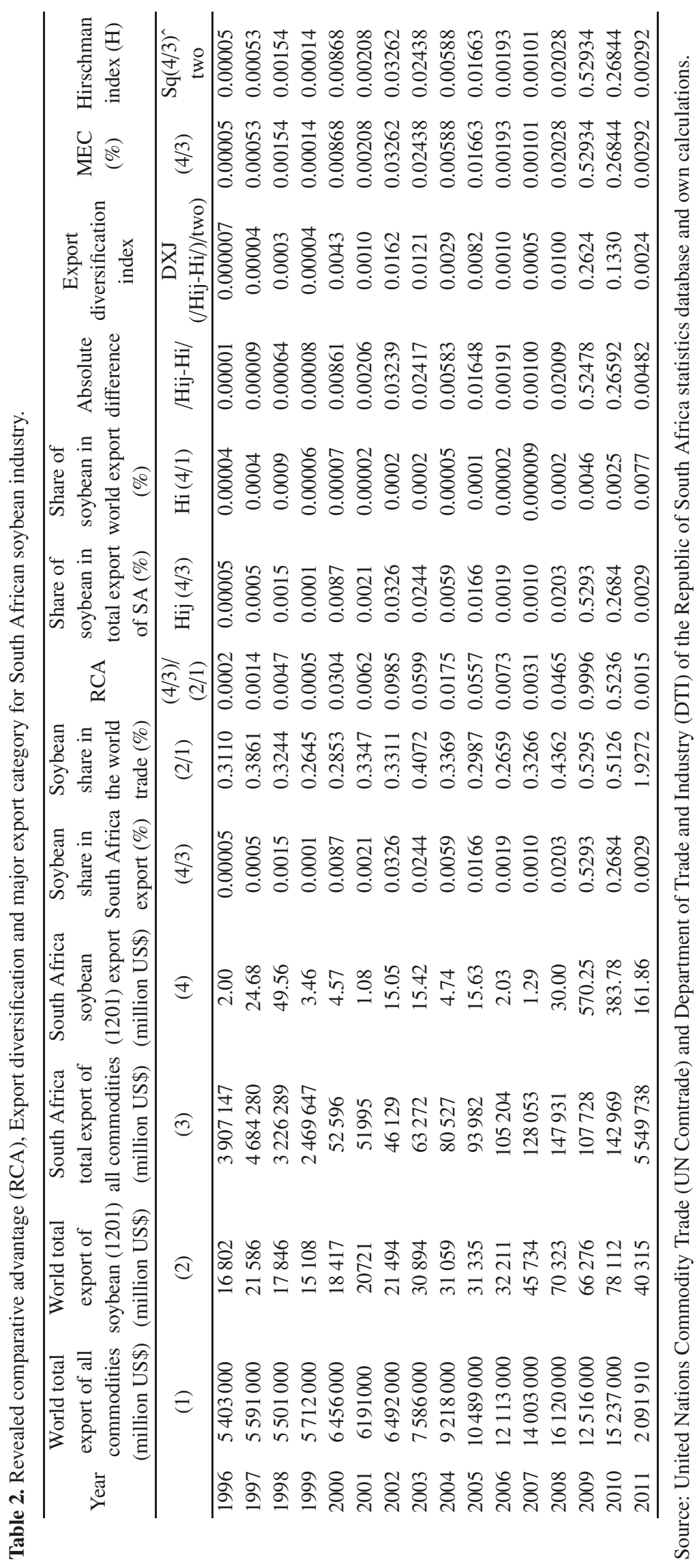


One possible application of RCA measures is to deduct the impact of changes in trade policies on an industry, sector or sub-sector. RCA is primarily based on relative export shares that could be biased due to distortions from various trade and non-trade barriers (Bahta, 2004).

\subsection{Export diversification index}

The value of index of trade concentration is close to zero, which indicates a less concentrated trade structure. The index of trade concentration or Hirschman index indicates that the soybean industry shows lower concentration throughout the 16 years; lower concentration reduces the impact of international trade risk due to the possibility of price fluctuation in the international market. Export diversification is likely to be a proxy for the widening of comparative advantage that comes with a more diversified economy (see Tab. 2).

\subsection{Major export category (MEC)}

The soybean product accounts in all years below 50 per cent, indicates that South Africa is not deemed to be too dependent on soybean product for export. No single category account for 50 per cent or more of total exports throughout 16 years (Tab. 2). The MEC measurement also indicates that South Africa does not depend on their international trade from soybean industry. Nin-Pratt et al. (2008) analysis the leading agricultural product for South Africa export defined according to the share of this product in this country's total agricultural export trade value and found that sugar cane (SITC 1701), wine (SITC 2204), oranges (SITC 0805), grapes (SITC 0806) and fuel wood (SITC 4401) ranked the top 5 for the entire decade (2000-2011). Together these 5 groups of commodities have a share of 34 and $30 \%$ of total agricultural exports in 2010 and 2011 respectively.

\subsection{Effective rate of protection (ERP) and nominal rate of protection (NRP)}

The Balassa ERP of soybean is -89.8 and -86.2 for Free State Province (FSP) and KwaZulu-Natal (KZN) Province respectively. The negative ERP indicates that the weighted input tariffs on soybean inputs amount is more than the output tariff; the soybean sector is taxed by government tariff policies. The NRP is higher than ERP, which implies that tariff applied on the output is higher than the tariff on inputs.

Other studies by Grönum et al., 2000 on Comparative advantage of dry land soybean production in Brits, North West province of South Africa using Policy Analysis Matrix (PAM) to determine the impact of government policy, and the result shows that soybean producers in South Africa are taxed as well.

\section{Summary, conclusion and recommendation}

The main aim of the study is to analyze the trade policy of the soybean industry in South Africa and applies theoretical
Table 3. Nominal and effective protection for 2010 .

\begin{tabular}{cccc}
\hline & Place & Balassa ERP & NRP \\
\hline \multirow{2}{*}{ Soybean } & FSP & -89.83 & 27.04 \\
& KZN & -86.26 & 50.39 \\
\hline
\end{tabular}

Note: FSP is Free State province, KZN is KwaZulu-Natal province, ERP is Effective rate of protection and NRP is Nominal rate of protection. Source: Author's calculation.

and empirical principles of RCA, Hirschman index (H), MEC, ERP and NRP to better understand the national pattern of production and export of soybean in South Africa using 4 digits SITC of soybean (1201) data of 1996-2011. The study indicates that The RCA of the soybean industry in South Africa has shown a revealed comparative disadvantage from 1996 to 2011. The index of trade concentration or Hirschman index indicates that the soybean industry shows lower concentration throughout 16 years. MEC measurement also indicates that South Africa does not depend their international trade from soybean industry. The ERP and NRP were also calculated, using the enterprise budget of 2009/2010 of the Free State Province (FSP) and KwaZulu-Natal (KZN) Province. The result shows that the ERP is negative; this indicates that the weighted input tariffs on soybean inputs amount to more than the output tariff. Thus, producers of soybean would be better off, everything else being equal, by not being protected through tariffs.

It should be stressed that no country is free from government policies and interventions which distort trade flows and therefore cause a high probability that the RCA index misrepresents true comparative advantages. RCA indices are therefore still significantly used in tracing out national comparative advantages.

It is evident that tariff liberalization in South Africa has been an ongoing process since the early 1970's, with the introduction of export subsidies and quantitative restrictions on import together with imposition of tariffs and other duties. According to Cassim et al. (2004) the key problem is that South Africa's tariff structure still remains cumbersome with some 50 ad valorem tariff bands, with over 7000 lines. It may be worth considering a highly simplified tariff structure with a greatly reduced number of ad valorem tariff lines. Although South Africa has reduced the overall tariff rate, the large number of different tariff bands render the system unwieldy to administer and not very transparent. In addition, the high degree of dispersion and discretion evident in South Africa's tariff regime is likely to send a confusing message to South African exporters and importers. In conclusion, a uniform tariff rate is likely to create higher efficiency in the economy while creating less arbitrary protection for the soybean industry. It will be easier to bring imported intermediate inputs into the country that are important for international competitiveness of firms, less rent seeking at customs and excise and less distortion in the economy.

Based on the results of this study the following recommendations can be made. The structure of the tariff schedule may have an important bearing on efficiency. An extremely dispersed and clumsy tariff structure implies that protections remain spotty and gains from openness may still be confined. 


\section{References}

ACET, African Centre for economic Transformation. 2014. The Soybean Agri-Processing Opportunity in Africa.

Bahta ST. 2004. The effect of the South African trade policy regime on the beef and maize sub-sector. Master thesis, University of the Free State, South Africa.

Balassa B. 1965. Trade Liberalization and Revealed Comparative Advantage. The Manchester school of Economic and Social Studies 33: 99-125.

Balassa B. 1977. Revealed Comparative Advantage Revisited: An analysis of relative export shares of the industrialized countries, 1953-1971. The Manchester school of Economic and Social Studies 45: 327-344.

BFAP, The Bureau for Food and Agricultural Policy projects. 2013. Available online on: www.thebioenergysite.com/articles/812/ soybean-production-in-south-africa (accessed 25 April 2015).

Cassim R, Onyango D, Van Seventer DE. 2004. The state of trade policy in South Africa. Trade and Industrial Policy Strategies (TIPS). Available online on: www.tips.org.za/files/501.pdf (accessed 06 April 2015).

Dlamini TZ, Tshabalala P, Mutengwa T. 2014. Soybeans production in South Africa. OCL 21: 1-11.

De Beer A. 2012. Soybean Cultivar Recommendations for 2012/2013. Potchefstroom: ARC-Grain Crops Institute. In: Dlamini TZ, Tshabalala P, Mutengwa T. 2014. Soybeans production in South Africa. OCL 21: 1-11.

DTI, Department of Trade and Industry. 2013. Availble online on: http://apps.thedti.gov.za/econdb/raportt/defaultrap.asp\#1 (accessed 8 March 2015)

Flatter F. 2002. Measuring the Impacts of Trade Policies: Effective Rates of Protection. Paper prepared as background material for a firm-level effective protection study to analyze the impacts of regional trade liberalization under the SADC Trade Protocol. http://qed.econ.queensu.ca/faculty/ flatters/writings/ff_measuring_impacts_of_trade_policy.pdf (accessed 15 April 2015).

Grain South Africa. 2013. Available online on: http://www.grainsa. co.za/ (accessed 4 April 2015).

Groenewald JA. 2001. Impediments to delivery of policy for growth with equity in South African agriculture. Unpublished report, Africa Institute for Policy Analysis and Economic Integration (AIPA).

Grönum CF, Van Schalkwyk HD, Du Plessis JH. 2000. The Comparative Advantage of Dry land Soybeans Production in Brits, North West. Agrekon 235-243.
Hausmann R, Klinge B. 2006. Structural Transformation and Patterns of Comparative Advantage in the Product Space.CID Working Paper No. 128.

Houck JP. 1986. Elements of agricultural trade policy. Macmillan Publishing Company, New York.

Khor M. 2005. The commodities crisis and the global trade in agriculture: problem and Proposal. Third World network.

Kraamwinkel A. 1998. Customs tariff policy. Poultry Bulletin 459463.

Leishman D, Menkhaus D, Whipplw G. 1999. Revealed Comparative Advantage and the Measurement of International Competitiveness for Agricultural Commodities: An Empirical Analysis of Wool Exporter. Paper presented at Western Agricultural Association Annual meeting. July 11-13. Fargo, ND.

Mikic M. 2005. Introduction to trade research II: Trade data and statistics: ARTNeT Capacity Building Workshop on Trade Research 22-25 March 2005.

NAMC, National Agricultural Marketing Council. 2011. The South African Soybean Value Chain.

Nin-Pratt A Diao, X, Bahta YT. 2008. Assessing Potential Welfare Impacts on Agriculture of a Regional Free Trade Agreement in Southern Africa. ReSAKSS Working Paper No. 15, International Food Policy Research Institute (IFPRI).

Rai DK. 2010. Asian Economic Integration and Cooperation: Challenges and Ways Forward for Pan-Asian Regionalism. Germen Institute of Global and Area Studies Working Paper No. 152.

SAFEX, South Africa Foreign Exchange Trading. 2013. Available online on: www.safex.co.za (accessed 19 April 2015).

Scott C. 2005. Measuring Up the measurement problem. The role of statistics in evidence- based policy making. CBMS Network Meeting. Available online on: http://www.pep-net.org/ fileadmin/medias/pdf/files_events/4th_colombo/proceed/scott. pdf (accessed 12 April 2015).

UN Comtrade, United Nations Commodity Trade Statistics Database.2013. Available online on: http://comtrade.un.org/ db (accessed 2 April 2015).

UNCTAD, United Nations Conference on Trade and Development. 2004. Handbook on Statistics. New York and Geneva: United Nations.

USAID, United State Agency for International Development. 2006. Has Trade liberalization in South Africa affected men and women differently? Prepared by development and training services Inc(dTS).

World Bank. 2013. Available online on: http://www.worldbank.org/ (accessed 20 April 2015).

Cite this article as: Yonas T. Bahta, Johan Willemse. The comparative advantage of South Africa soybean production. OCL 2016, 23(3) A301. 